\title{
Reward System as a Strategic HRM Determining Work Productivity in Hospitality Organizations
}

\author{
Harianto Respati Boge Triatmanto \\ Faculty of Economics and Business, University of Merdeka Malang, Indonesia
}

This research was funded by Kemenristek DIKTI in 2019

\section{Abstract}

This study aims to examine the strategic Human Resource Management (HRM) on organizational performance and enrich the scientific field of organizational performance. There is still not much research on organizational performance in the hospitality industry. Research locations in Malang Raya include Malang City, Malang District and Batu City (Indonesia). The research design is quantitative experimental. Research respondents were hotel personnel managers or assistant managers who worked for more than one year. Each hotel is represented by one respondent. The study population was 117 hotels. The method of determining the sample is a census. Questionnaire as an instrument to collect data. Data analysis techniques using description analysis and linear regression. The results of the research prove that strategic HRM has a significant effect on organizational performance and a rewards system is highly needed by employees when an industry is in a highly competitive position.

Keywords: strategic HRM, organizational performance, reward system, productivity, hospitality

DOI: $10.7176 / \mathrm{EJBM} / 11-36-04$

Publication date: December $31^{\text {st }} 2019$

\section{INTRODUCTION}

In the current decade, hotel organizations face a complicated situation and high competition, so that the role of human resources remains a mainstay of a hotel (Madera et al., 2017), moreover the marketing activities of the hospitality industry are highly dependent on communication technology. Face-to-face interactions between employees and customers in terms of (1) service quality, (2) maintaining customer loyalty, and (3) satisfaction (Baum, 2015; Tracey, 2014) being a strategic activity for the hotel industry. These three points show that human resources are the key to the success of a hotel business.

A strategy is an activity approach that is planned and integrated to achieve a goal. Hotels need a strategy to create and maintain service quality, customer loyalty, and satisfaction in order to win the competition. Recent studies in the field of strategic HRM and competition in the literature on hospitality have grown rapidly. The explanation of how strategic HRM to create organizational performance in the hospitality and tourism industry is still not much (Madera et al., 2017). As stated by Madera et al. (2017) that strategic HRM is a way to carry out HR functions (recruitment, selection, training, compensation, and benefits) to improve organizational performance. Strategic HRM focuses on implementing the company's HRM system and organizational performance (Huselid and Becker, 2010).

Some previous research results show that strategic HRM has a significant impact on corporate work systems that are oriented towards improving organizational performance (Paauwe, 2009; Becker and Huselid (2006); Combs et al., 2006). Some of the results of previous studies have proven that organizational performance increases due to strategic HRM especially reward systems and training in line with competitive strategies and business goals.

Malang Raya as a tourist area, especially in Batu city and Malang Regency, as a place for education, industry, and business is in Malang City. Lately, the growth of hotel visits has been increasing followed by the addition of new hotels, especially in the cities of Malang and Batu. Of course, strategic HRM is needed. For this reason, researchers are interested in knowing the effect of the twelve strategic components of HRM on organizational performance. The results of this study are useful for hotel managers, especially helping in improving the performance of hotel organizations.

\section{LITERATUR REVIEW}

\section{Human Resource Management}

There is a version that narrates about HRM and of course, there are many versions of this. An explanatory statement about HRM appeared in 1984 at Michigan School, stated by Fombrun et al. (1984). They explained that the human resource system and organizational structure must be managed in accordance with organizational goals. Fombrun et al. (1984) have introduced four HRM functions such as selection, employee appraisal, rewards, and employee development. These four HRM functions have been developed following the business progress or organizational orientation and many experts describe these four functions as strategic HRM from time to time.

Boxall et al. (2007) hold that HRM was the management of work and workers to achieve company goals. 
Armstrong (2008) explains that human resource management in companies was a logical and conceptualized way of properly managing employees as corporate assets that are managed individually or in groups to achieve organizational goals. In general, HRM areas include work programs related to organizational effectiveness, human capital management, knowledge management, gift management, employee relations, meeting diverse needs and bridging the gap between rhetoric and reality (Armstrong, 2008)

\section{Strategy}

The strategy has two basic meanings, namely what is to be achieved and how to achieve it (Armstrong, 2008). The strategy includes the dimensions of time, activities and achievements. A good strategy is that the organization is able to carry out the functions of the dimensions of time, activities, and achievements carefully. To maximize competitive advantage requires a strategy, which is to integrate the capabilities and resources of the company with existing external opportunities. Hofer and Schendel (1986) conclude that top management has a job at the strategic level that is matching effectively and efficiently from time to time between organizational competencies (internal resources and skills) with opportunities, risks that change due to external environmental conditions.

Many experts explain the strategy with various versions. The 1960s such as Chandler (1962) explained that strategies were more focused on setting long-term goals and objectives and taking action to allocate company resources to achieve goals. In the 1970s, Child (1972) described the strategy as a fundamental and critical choice in setting business goals. In the 1980s, Rumelt (1984) described the strategy as a way of utilizing organizational unique resources when the external environment changed. In 1990 there was an environmental change that is high-level competition, so the meaning of the strategy shifted a little as directed by Johnson and Scholes (1993) that the strategy was a setting the direction of the organization for the long term, integrating resources and changes optimally, especially for market control, customers, clients and to meet stakeholder expectations. Until the 2000s, experts still agreed with the definition of Johnson and Scholes, only that there was an additional use of communication technology and equipment that was relevant to adjusting the industrial revolution 4.0. The concept of strategy is based on the objectives of achieving a competitive advantage, utilization of organizational / company resources, and management levels (Armstrong, 2008).

\section{Strategy HRM}

Armstrong (2008) explains the HRM Strategy is a careful and logical approach in utilizing human resources to be more valuable and to make HR policies and practices for organizational purposes. Armstrong's thinking explains that HRM was related to important resources to achieve competitive advantage (Hendry and Pettigrew, 1986), Cooperation between line managers and subordinates to solve business problems (Schuler and Walker, 1990), and successful organizations were organizations that are able to align between practices HR and business through a strategy (Batt, 2007). Tracey (2014) discusses HRM strategic into five functions such as staffing, training, performance appraisal and compensation, and benefits.

In general, the aim of HRM is to ensure that the company's success is due to the ability of individuals or groups in the company's organization. There are twelve strategic HRM to achieve the success of the company's organization stated by Caldwell (2004), namely:

1. Good governance for an organization's competitive advantage (HR governance)

2. Alignment of HRM policies with company business policies (HRM alignment with business)

3. Alignment of policies, work procedures and HR systems (Alignment of work procedures and systems)

4. Organizational quick response to business changes (Business response)

5. Reliable work team (work team)

6 . Focus on customers (Focus on customers)

7. Develop human resource knowledge (Knowledge HR)

8. Reward system

9. Employee involvement through communication (Employee involvement)

10. Employee commitment

11. Responsibility

12. Adequate organizational facilities (Organizational Facilities)

\section{Organizational Performance}

Performance in organizations consists of various dimensions, both financial and non-financial. This performance dimension is used to measure the success of an organization (Jang and Park, 2011; Venkatraman and Ramanujam, 1986). Sainaghi (2010) has conducted performance measurements in the hotel industry for 20 years, and concluded that hotel performance measurements are more appropriate using operational performance measures (sales volume, occupancy rates, efficiency levels, market segments, service quality, service innovation, and customer satisfaction) and financial performance (stock prices, financial ratios, profits). According to Kim et 
al. (2013) for the hotel sector that organizational performance was the achievement of organizational goals by considering six things namely long-term profit, revenue growth, job satisfaction, employee work productivity, good intentions, and service quality.

A study conducted by the International Research Center (IDRC) found several measurements of organizational performance in terms of effectiveness, efficiency, relevance and financial viability (Lusthaus et al., 1999). Carton (2006) describes treatises on organizational performance over time. The results of Cartom's tracer study (2006) explained that there are five views/perspectives in measuring organizational performance, namely accounting perspective, balanced scorecard, strategic management, entrepreneurship, and microeconomics.

Ball and Brown (1968); Beaver (1968); Lev (1989) has argued that organizational performance can be observed from organizational financial flows. This financial flow is able to show income and expenditure information. However, Kaplan has another view that to know the performance of an organization was not only from financial information because financial information is the result of past actions but also needs an operational plan for the future, which can be calculated as organizational performance. Therefore, Kaplan (1984) argues that a combination of financial information and operational management was needed to measure organizational performance. Barnard (1938) and Drucker (1954) view that effective organizations were organizations that are able to survive to achieve goals. Ansoff (1965) proposed that the main measure of organizational performance was returned on investment. Ansoff at that time had estimated that stakeholders had an interest in the company's profits. Freeman (1984) explains that organizational performance was the achievement of organizational goals. As long as the organization can combine the interests of the company and stakeholders. Porter (1985) has argued that business goals are needed to meet organizational performance for the necessary strategies to obtain a competitive advantage. At that time, Bracker and Pearson, (1986); Chandler and Jansen, (1992); Slevin and Covin, (1995) have the view that organizational performance was very relevant to the perspective of entrepreneurial goals. So as to achieve organizational performance it requires strategies and entrepreneurship as well as fulfilling the wishes of stakeholders.

\section{Strategic HRM and Organizational Performance}

The main objective of HRM Strategic namely performance includes business performance, organizational performance, organizational performance, and other performance. Some experts have the same view that employee welfare must be a major concern. In the public, private, and voluntary sectors, they have different objectives, such as public service performance, profit performance, and charity function performance. The premise of HRM is that human resource policies are implemented effectively in order to make an impact on organizational performance. To achieve this, a strategy is needed. A number of studies that have been conducted on how strategic HRM affects organizational performance show different and conflicting results (Armstrong, 2008). Tracey's literature (2014) focuses more on the topic of discussion between strategic HRM and organizational performance. Madera et al. (2017) explained that strategic HRM is a way to carry out the function of HRM strategy to improve organizational performance. Caldwell (2004) introduces 12 functions of HRM strategy, then the hypothesis formulation (H1) is as follows (see Figure 1):

H1: The twelve functions of the HRM strategy have a significant effect on organizational performance.

\section{METHODOLOGY}

\section{Research design}

This study chose locations in Malang Raya including Malang City, Malang District, and Batu City. The study was conducted in 2019 for three months. The unit of analysis selected is all types of hotels in Malang. There are 117 hotels in Malang (one to five-star hotels). Each hotel is represented by one person to fill out a questionnaire. Selected respondents are hotel personnel managers or assistant managers who are responsible for operating a hotel for at least more than one year. Each respondent filled out a questionnaire and assessed the performance of his hotel organization compared to direct competitors during the past year. The research instrument used a Likert scale questionnaire that is five choices consisting of choice 1 is strongly disagree with choice 5 is strongly agree, choice 3 is neutral. The method for determining samples uses the census method so that the unit of analysis for this study was 117 respondents. Data analysis techniques using description analysis and linear regression assisted with the AMOS (Analysys Moment Of Structure) program. Information on the number of hotels is presented in Table 1.

Table 1. A number of hotels in Malang Raya.

\begin{tabular}{|l|l|l|l|}
\hline No. & \multicolumn{1}{|c|}{ Location } & \multicolumn{1}{c|}{ Sumber of Hotels } & \multicolumn{1}{c|}{ Source } \\
\hline 1 & Malang city & 57 & Wikipedia.2019 \\
\hline 2 & Malang Regency & 29 & Kabupaten Malang.2019 \\
\hline 3 & Batu City & 31 & Wikipedia.2019 \\
\hline Amount & 117 & \\
\hline
\end{tabular}




\section{Research variables}

This type of research is a quantitative experimental type, using the positivist paradigm approach. There is one independent variable, that is, strategic HRM measured by twelve indicators and one dependent variable, Organizational Performance, which is measured by six indicators. The relationship between variables and indicators is reflectively presented in Figure 1 and an explanation of the notation of variables and indicators is presented in Table 1.

Table 2. Research Variables and Indicators.

\begin{tabular}{|c|c|c|c|}
\hline Independent variables and indicators & & Dependent variables and indicat & \\
\hline X-Strategic HRM & & Y- Organizational Performance & \\
\hline X1- HR Management & \multirow{12}{*}{$\begin{array}{c}\text { Caldwell } \\
(2004)\end{array}$} & Y1- Long-term Profit & \multirow{12}{*}{$\begin{array}{c}\text { Kim et } \\
\text { al. } \\
(2013)\end{array}$} \\
\hline X2- Alignment of HRM Policy with Business & & Y2- Revenue Growth & \\
\hline $\begin{array}{l}\text { X3- Alignment of Work Procedures and HR } \\
\text { Systems }\end{array}$ & & Y3- Job satisfaction & \\
\hline X4- Business response & & Y4- Employee Work Productivity & \\
\hline X5- Work team & & Y5- Quality of Service & \\
\hline X6- Customer Focus & & & \\
\hline X7- HR Knowledge & & & \\
\hline X8- Reward System & & & \\
\hline X9- Employee Engagement & & & \\
\hline X10- Employee Commitment & & & \\
\hline X11- Responsible & & & \\
\hline X12- Organizational Facilities & & & \\
\hline
\end{tabular}

Conceptual Framework and Research Hypotheses are also presented in Figure 1.

Figure 1. Conceptual Framework and Research Hypothesis

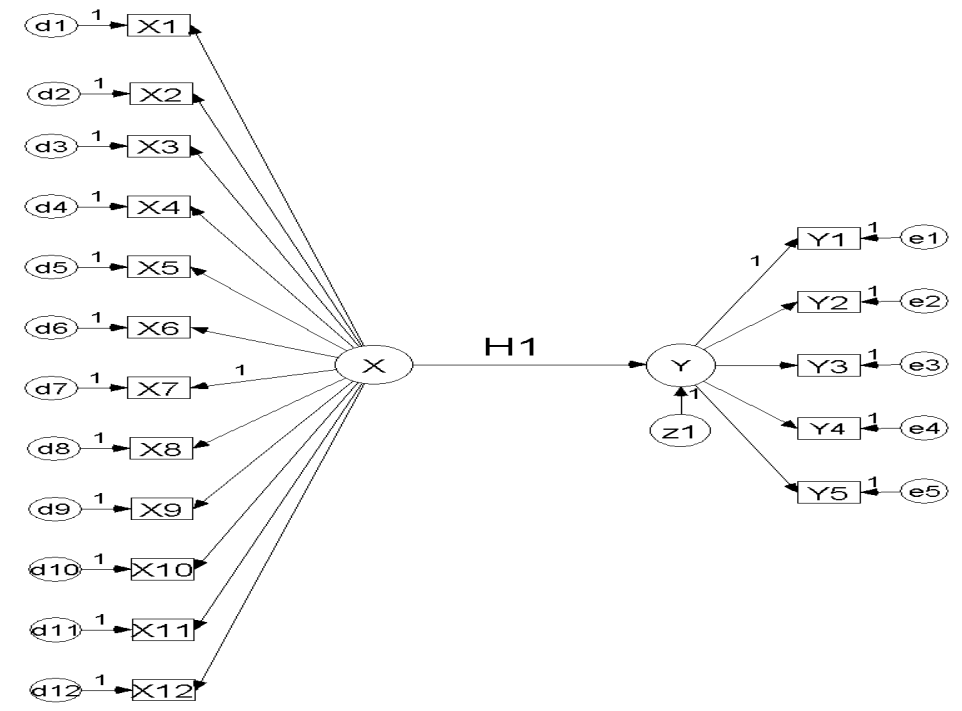

\section{ANALYSIS RESULTS}

\section{Data collection and test instruments}

Data collected as many as 105 units from 117 units. The research instrument testing used correlation techniques for validity testing and Chronbach's Alpha formula for reliability testing. The results of testing the instrument have shown that the items of the questionnaire respondents answered were valid and reliable. Each instrument item has a correlation number with an error probability level of less than 5\% (see the r-stat column in Table 2) and two variables have a Chronbach's Alpha value each exceeding the t-table (0.195) (see Table 2). 
Table 3. Results of statistical analysis

\begin{tabular}{|c|c|c|c|c|c|c|c|}
\hline $\begin{array}{c}\text { Independent variables and } \\
\text { indicators }\end{array}$ & r-stat & load & mean & $\begin{array}{l}\text { Dependent variables } \\
\text { and indicators }\end{array}$ & r-stat & load & mean \\
\hline X-Strategic HRM & & & & $\begin{array}{l}\text { Y- Organizational } \\
\text { Performance }\end{array}$ & & & \\
\hline X1- HR Management & $0,365^{*}$ & $0,580^{*}$ & 3,59 & Y1- Long-term Profit, & $0,765^{*}$ & $0,595 *$ & 4,03 \\
\hline $\begin{array}{l}\text { X2- Alignment of HRM } \\
\text { Policy with Business }\end{array}$ & $0,771^{*}$ & $0,730^{*}$ & 4,09 & Y2- Revenue Growth, & $0,833^{*}$ & $0,739^{*}$ & 4,01 \\
\hline $\begin{array}{l}\text { X3- Alignment of Work } \\
\text { Procedures and HR Systems }\end{array}$ & $0,744 *$ & $0,742 *$ & 4,01 & Y3- Job satisfaction, & $0,860 *$ & $0,743 *$ & 3,85 \\
\hline X4- Business response & $0,761^{*}$ & $0,721^{*}$ & 4,30 & $\begin{array}{l}\text { Y4- Employee Work } \\
\text { Productivity, }\end{array}$ & $0,910^{*}$ & $0,965 *$ & 4,45 \\
\hline X5- Work team & $0,657^{*}$ & $0,651^{*}$ & 4,25 & Y5- Quality of Service & $0,886^{*}$ & $0,940^{*}$ & 4,02 \\
\hline X6- Customer Focus & $0,749 *$ & $0,721 *$ & 4,02 & & & & \\
\hline X7- HR Knowledge & $0,738^{*}$ & $0.720 *$ & 4,05 & & & & \\
\hline X8- Reward System & $0,802^{*}$ & $0,812^{*}$ & 4,35 & & & & \\
\hline X9- Employee Engagement & $0,794 *$ & $0,788^{*}$ & 4,01 & & & & \\
\hline X10- Employee Commitment & $0,767^{*}$ & $0,749 *$ & 3,90 & & & & \\
\hline X11- Responsible & $0,762 *$ & $0,754^{*}$ & 3,98 & & & & \\
\hline X12- Organizational Facilities & $0,612 *$ & $0,530 *$ & 3,89 & & & & \\
\hline \multicolumn{8}{|c|}{$\begin{array}{l}\text { The probability level is less than } 0.05 \\
\text { Cronbach's Aplha for X1 is } 0,916 \text { and X } 2 \text { is } 0,817 \\
\text { r-table }(\alpha=0,05 \text { and degree of freedom }=105) \text { is } 0 \text {, }\end{array}$} \\
\hline
\end{tabular}

The results of testing the validity of the correlation test for the HRM Strategy variable indicate that the reward system indicator has the highest correlation value compared to other indicators. This figure shows that respondents are very familiar with the implementation of the reward system where they work in a hotel. The results of the validity test for organizational performance variables indicate that the indicator of work productivity gets the highest correlation value compared to other indicators.

This figure shows that respondents understood that lately, they had done an optimal level of productivity. HRM strategic variables have twelve indicators, each indicator has a loading factor value above 0.5 (see Table 2 in the Load column) as well as for five indicators of organizational performance having a load value of more than 0.5 . This means that the indicators are able to reflect the measured variables. The structural equation model results as in Figure 2.

Figure 2. Research Model Results

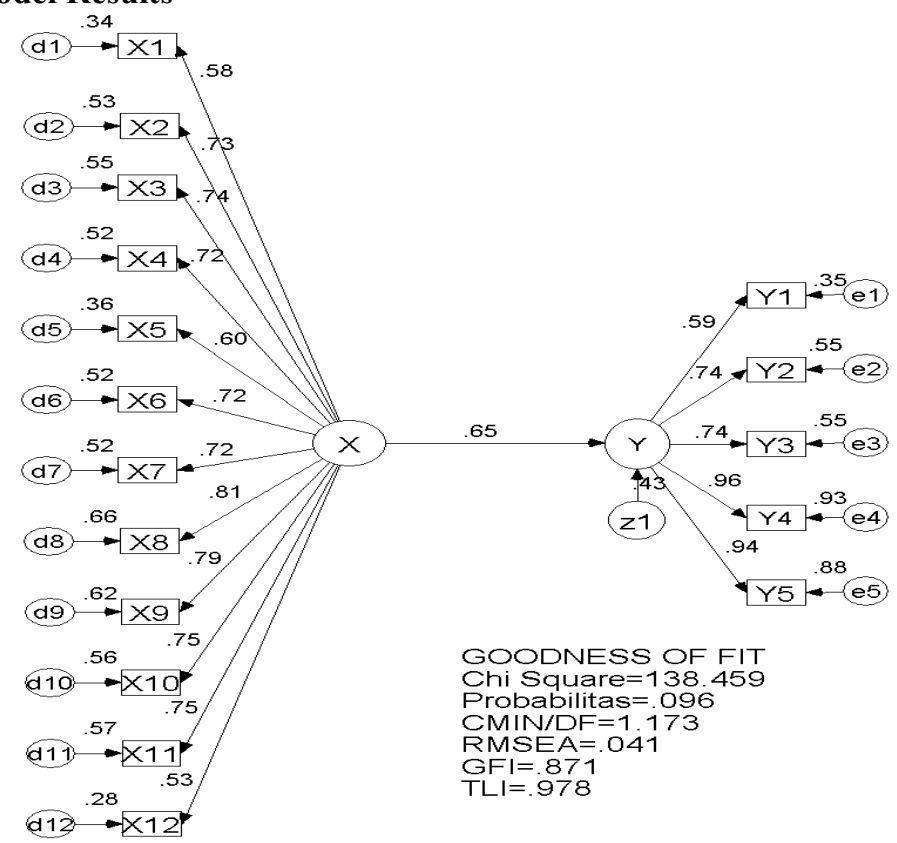

The structural equation model results obtained a Chi-square-statistical value $(130,459)$ greater than the Chisquare-table value $(93,918)$ with a probability level of 0.096 greater than the cut-off value $(0.05)$, this comparison explains that the hypothesis null statistics accepted. That is, there is no significant difference 
between the input data with the structural equation models built in this research. The acceptance of the null hypothesis shows the model in Figure 2 is accepted as the analysis model. The results of testing between variables are presented in Table 3. The results of the structural equation modeling test show there is a strategic HRM effect on organizational performance

Tabel 4. Regression Weights

\begin{tabular}{|cc|c|c|c|c|c|c|}
\hline \multicolumn{2}{|c|}{ Path } & $\begin{array}{c}\text { Estimate } \\
\text { Unstandardized }\end{array}$ & $\begin{array}{c}\text { Estimate } \\
\text { Standardized }\end{array}$ & S.E. & C.R. & P. & result \\
\hline $\mathrm{X} \rightarrow \mathrm{Y}$ & 0,441 & 0,654 & 0,091 & 4,851 & 0,000 & H1 received \\
\hline
\end{tabular}

\section{DISCUSSION AND CONCLUSION}

HR Management of the hotel industry in Malang Raya according to managers' perceptions is still not full toward the target point of an organization's performance. Most famous hotels experience the same thing, namely the high rate of labor turnover. Employees who have increased skills have high potential to switch to work in another hotel. The results of respondents' perceptions about the alignment of HRM policies with hotel business policies, the alignment of work procedure policies with the role in the organizational structure so far are considered to be still relevant, especially in selecting and evaluating the work of employees under the responsibility of the supervisor. Hotel organizations in Malang Raya on average are very fast in responding to market needs, especially during the long holiday season. Malang Raya is a tourist, educational, industrial and business area. The average hotel has a reliable team and employees always focus on customers and professionals in handling the service problems of guests who visit and stay. Hotel managers agree that the key to the success of a hotel is the knowledge of employees, the reward system and communication between employees. In addition, the growth of a hotel is also determined by unique things such as the location of the hotel, natural panorama and layout of the hotel layout into its own competitive advantage. Managers still feel something lacking, namely the problem of employee commitment, responsibilities and hotel facilities for employees are still inadequate.

Organizational performance for hotels in Malang is more visible in high levels of employee productivity. The employees are busy carrying out arranged services with a tight schedule. Managers are preoccupied with new innovations aimed at entertaining visitors and customers.

According to managers' perceptions, most hotels that have been studied have predictable rates of profit and income growth.

The results showed that strategic HRM had a significant effect on organizational performance. An important finding of this research is the hotel industry in Malang, that the implementation of reward systems such as bonuses, overtime incentives and salaries received is able to fully encourage employee work productivity. The findings of this study support the results of research conducted by Paauwe (2009), Becker and Huselid (2006), and it can be justified that a reward system is needed in an industry that is experiencing hypercompetitive, one of which is the hotel industry.

\section{SUGGESTIONS FOR PRACTITIONERS, AND FUTURE RESEARCHERS}

The core results of the findings of this study are that the rewards system is highly needed for employees when an industry experiences high competition. For this reason, hotel managers are advised to always establish good communication between employees to find out what level of skills are needed to improve organizational performance. Of course, the hotel reward system is recommended to be a standard system, so there is no need for bureaucracy and policies.

Basically, the strategic HRM focus on company performance or organizational performance, this has been proven from the results of research studies on HRM (Huselid and Becker, 2010). However, there are several other views such as that proposed by Buller and McEvoy (2012), Guest (2011) and Paauwe (2009) have explained that the link between HRM and performance is still unclear and mediation is needed that bridges between HRM and performance. Mediation in question is the human capital, knowledge, and skills of employees (Wright and McMahan, 2011). Chisholm and Nielsen (2009) suggested social capital as an HRM mediator to performance.

This research measures strategic HRM using the theory put forward by Caldwell (2004) and measures organizational performance by Kim et al. (2013). For future researchers, they can refer to the theory proposed by Tracey (2014), namely staffing, training, performance appraisal, compensation, and benefits to measure HRM strategic. For performance in the hotel industry, it is recommended to refer to Sainaghi (2010) which measures performance into two indicators namely operational performance (sales volume, occupancy rate, efficiency level, market segment, service quality, service innovation, and customer satisfaction) and financial performance (stock price, ratio finance, profit). 


\section{References}

Ansoff, H.I. (1965), Corporate Strategy: An Analytic Approach to Business Policy for Growth and Expansion, New York: McGraw-Hill.

Ball, R. and P. Brown (1968), "An empirical evaluation of accounting income numbers", Journal of Accounting Research, Autumn, 159-78.

Barnard, C. (1938), The Functions of the Executive, New York: John Wiley \& Sons.

Batt, R. (2007), Service strategies, in Oxford Handbook of Human Resource Management, ed Peter Boxall, John Purcell, and Patrick Wright, Oxford University Press, Oxford.

Baum, T. (2015), "Human resources in tourism: still waiting for change? A 2015 reprise", Tourism Management, Vol. 50, pp. 204-212.

Beaver, W. (1968), "The information content of annual earnings announcements", Journal of Accounting Research, Supplement, pp. 67-92.

Becker, B. and Huselid, M. (2006), "Strategic human resources management: where do we go from here?", Journal of Management, Vol. 32 No. 6, pp. 898-925.

Boxall, P F, Purcell, J and Wright, P. (2007), Human resource management: scope, analysis and significance, in Oxford Handbook of Human Resource Management, ed Peter Boxall, John Purcell, and Patrick Wright, Oxford University Press, Oxford.

Bracker, J.S. and J.N. Pearson (1986), "Planning and financial performance of small, mature firms", Strategic Management Journal, Vol.7 No.6, pp. 503-22.

Buller, P. and McEvoy, G. (2012), "Strategy, human resource management and performance: Sharpening line of sight”, Human Resource Management Review, Vol. 22 No. 1, pp. 43-56.

Caldwell, R (2004), "Rhetoric, facts and self-fulfilling prophesies: exploring practitioners' perceptions of progress in implementing HRM", Industrial Relations Journal, Vol.35 No.3, pp. 196-215.

Carton, Robert B., and Charles W. Hofer (2006), Measuring Organizational Performance: Metrics For Entrepreneurship and Strategic Management Research. Edward Elgar Publishing Limited.Uk

Chandler, AD. (1962), Strategy and Structure, MIT Press, Boston, MA

Chandler, G.N. and E. Jansen (1992), "The founder's self-assessed competence and venture performance", Journal of Business Venturing, Vol.7 No.3, pp. 223-36.

Child, J. (1972), "Organizational structure, environment, and performance: the role of strategic choice", Sociology, Vol.6 No.3, pp. 1-22.

Combs, J., Liu, Y., Hall, A. and Ketchen, D. (2006), "How much do high-performance work practices matter? A meta-analysis of their effects on organizational performance", Personnel Psychology, Vol. 59 No. 3, pp. 501-528.

Drucker, P. (1954), The Practice of Management, New York: Harper \& Row.

Fombrun, C.J, Tichy, N.M. and Devanna, M A.(1984), Strategic Human Resource Management, Wiley, New York.

Freeman, R.E. (1984), Strategic Management: A Stakeholder Approach, Boston, MA: Pitman.

Guest, D.E. (2011), "Human resource management and performance: still searching for some answers", Human Resource Management Journal, Vol. 21 No. 1, pp. 3-13.

Hendry, C, and Pettigrew, A (1986), "The practice of strategic human resource management", Personnel Review, Vol. 15, pp. 2-8.

Hofer, C. W., and Schendel, D. (1986), Strategy Formulation: Analytical concepts, West Publishing, New York.

Huselid, M.A. and Becker, B.E. (2010), "Bridging micro and macro domains: workforce differentiation and strategic human resource management", Journal of Management, Vol. 37 No. 2, pp. 421-428.

Huselid, M.A., and Becker, B.E. (2010), "Bridging micro and macro domains: workforce differentiation and strategic human resource management", Journal of Management, Vol. 37 No. 2, pp. 421-428.

Jang, S. and Park, K. (2011), "Hospitality finance research during recent two decades: subjects, methodologies, and citations", International Journal of Contemporary Hospitality Management, Vol. 23 No. 4, pp. 479497

Johnson, G., and Scholes, K. (1993), Exploring Corporate Strategy, Prentice-Hall, Hemel Hempstead

Kabupaten Malang.2019. . Acess in November 2019

Kaplan, R. (1984), "Yesterday’s accounting undermines production”, Harvard Business Review, July/August, 95-101.

Kim, Taegoo Terry, Gyehee Lee, Soyon Paek, Seunggil Lee. (2013), "Social capital, knowledge sharing and organizational performance: What structural relationship do they have in hotels?". International Journal of Contemporary Hospitality Management, Vol. 25 No. 5, pp. 683-704

Lev, B. (1989), "On the usefulness of earnings and earnings research: lessons and directions from two decades of empirical research", Journal of Accounting Research, Vol.27 (Supplement), pp. 153-201

Lusthaus, Charles, and Marie-Hélène Adrien, Gary Anderson, Fred Carden (1999), Enhancing Organizational 
Performance. Published by the International Development Research Centre. Canada.

Madera, Juan M., Mary Dawson, Priyanko Guchait and Amanda Mapel B. (2017), "Strategic human resource management research in hospitality and tourism", International Journal of contemporary hospitality management, Vo.29 No.1, pp. 48-67.

Michael, Armstrong, (2008), Strategic Human Resource Management: A Guide To Action. 4th Edition, India. Replika Press Pvt Ltd.

Paauwe, J. (2009), "HRM and performance: achievements, methodological issues, and prospects", Journal of Management Studies, Vol. 46 No. 1, pp. 129-142.

Paauwe, J. (2009), "HRM and performance: achievements, methodological issues, and prospects", Journal of Management Studies, Vol. 46 No. 1, pp. 129-142.

Porter, M.E. (1985), Competitive Advantage, New York: Free Press.

Rumelt, R. P. (1984), Towards a strategic theory of the firm, in Competitive Strategic Management, ed P C Nystrom and W H Starbuck, Prentice-Hall, Englewood Cliffs, NJ.

Sainaghi, R. (2010), "Hotel performance: state of the art", International Journal of Contemporary Hospitality Management, Vol. 22 No. 7, pp. 920-952.

Schuler, R S, and Walker, J. (1990), "Human resources strategy: focusing on issues and actions", Organization Dynamics, Summer, pp 5-19.

Slevin, D.P. and J.G. Covin (1995), "Entrepreneurship as firm behavior: a research model”, in J.A. Katz and R.H. Brockhaus (eds), Advances in Entrepreneurship, Firm Emergence and Growth, Greenwich, CT: JAI Press, $175-224$.

Tracey, J. (2014), "A review of human resources management research: the past 10 years and implications for moving forward”, International Journal of Contemporary Hospitality Management, Vol. 26 No. 5, pp. 679705 .

Venkatraman, N. and Ramanujam, V. (1986), "Measurement of business performance in strategy research: a comparison of approaches", Academy of Management Review, Vol. 11 No. 4, pp, 801-814.

Wikipedia (2019). Acess on November 2019.

Wikipedia (2019). Daftar hotel di kota https://id.wikipedia.org/wiki/Daftar_hotel_di_Kota_Malang\#Bintang_Lima. Acess on November 2019. 